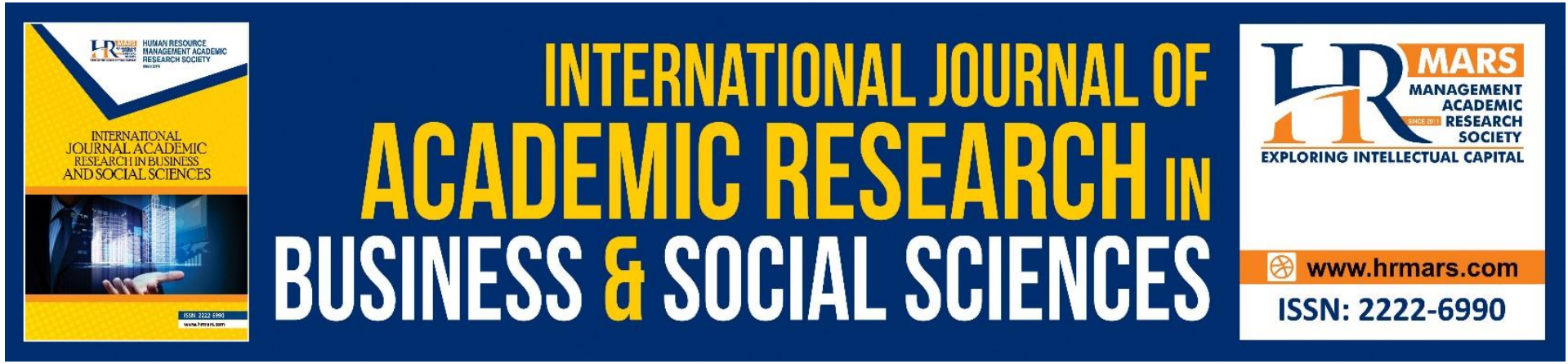

\title{
Factors Influencing Housing Purchase Decision
}

\section{Mohammad Mujaheed Hassan, Nobaya Ahmad, Ahmad Hariza Hashim}

To Link this Article: http://dx.doi.org/10.6007/IJARBSS/v11-i7/10295 DOI:10.6007/IJARBSS/v11-i7/10295

Received: 17 May 2021, Revised: 19 June 2021, Accepted: 01 July 2021

Published Online: 25 July 2021

In-Text Citation: (Hassan et al., 2021)

To Cite this Article: Hassan, M. M., Ahmad, N., \& Hashim, A. H. (2021). Factors Influencing Housing Purchase Decision. International Journal of Academic Research in Business and Social Sciences, 11(7), 429-443.

\section{Copyright: @ 2021 The Author(s)}

Published by Human Resource Management Academic Research Society (www.hrmars.com)

This article is published under the Creative Commons Attribution (CC BY 4.0) license. Anyone may reproduce, distribute, translate and create derivative works of this article (for both commercial and non-commercial purposes), subject to full attribution to the original publication and authors. The full terms of this license may be seen at: http://creativecommons.org/licences/by/4.0/legalcode

Vol. 11, No. 7, 2021, Pg. 429 - 443

Full Terms \& Conditions of access and use can be found at http://hrmars.com/index.php/pages/detail/publication-ethics 


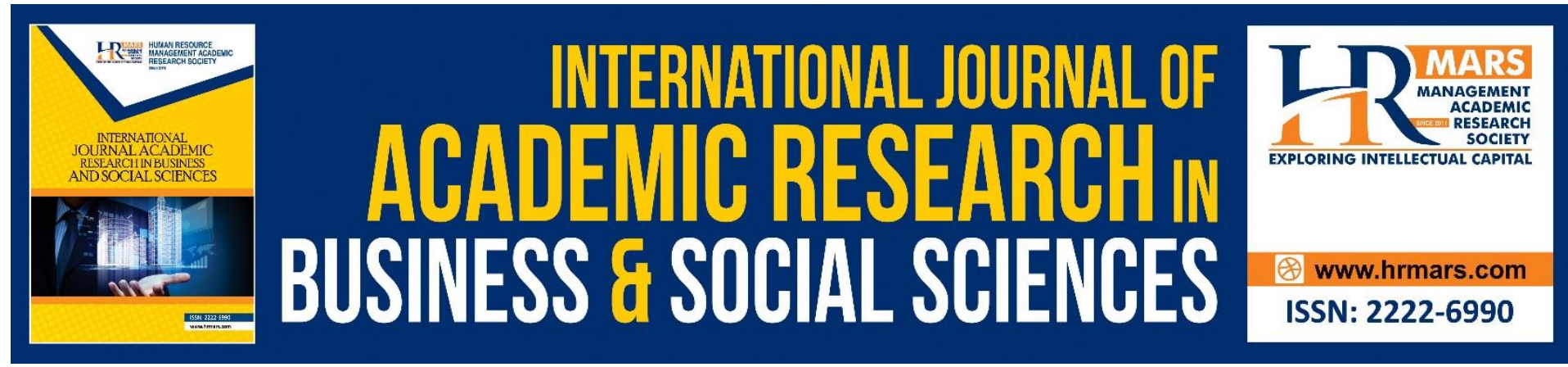

\title{
Factors Influencing Housing Purchase Decision
}

\author{
Mohammad Mujaheed Hassan ${ }^{1}$, Nobaya Ahmad², Ahmad \\ Hariza Hashim ${ }^{3}$ \\ Faculty of Human Ecology, Universiti Putra Malaysia, Malaysia \\ 1Email: mujaheed@upm.edu.my
}

\begin{abstract}
House is among the essentials for human beings, which also functions as a protection and sustenance for household living. Although awning a "dream home" is the most desired life goal of individuals, it takes various aspects into account. Furthermore, provided that housing market results are based on diverse factors, this article attempts to identify and analyse the elements impacting a buyer's housing purchase decision. However, the remaining unpurchased residential units in the nation are the results of inconsistent pricing, less appealing and other several factors. Generally, the government and private developers must identify primary elements influencing house purchase, prevent abandoned projects, guarantee the successful operation of projects, and fulfil the homeowners' needs for the long term. Notably, this article is beneficial as a reference for future projects by researchers, developers, the government, and other professionals related to the housing industry.
\end{abstract}

Keywords: Purchase Decision Factors, Housing, Housing Preferences

\section{Introduction}

A house is an essential need, which provides peace and comfortable space for a family. As a developing nation, Malaysia is involved with various emerging innovations, particularly in the residual sector. Various new forms and feasible destination are involved in these innovations. Despite the diversity in housing choice in terms of size, category, location, design, cost, and materials (Abdullah et. al., 2012), it remains a challenging process. Housing choice is also associated with some elements influencing the decision-making for house purchase, which varies for each individual.

In the housing market, housing choice among buyers is essential due to its function in predicting housing demand, which offers indirect assistance for the government to stabilise housing policies and further promote house ownership (Abdullah et al., 2012). Essentially, the comprehension of housing preference is crucial for the buyers' decision-making, particularly first-time buyers (Khan et al., 2017). A study by Reid (2013) recorded various elements influencing housing preferences, namely the relative price of ownership over rent, fortune, salary, credit constraints, destination, household features, house category, cost, and distance from service and product facilities, accessibility, and open space. Other elements are convenient to access to public transport, proximity to school and commercial space (Fierro et al 2009). Accordingly, Zyed et al (2016) recorded other elements influencing housing 
affordability, namely house cost, household salary, and housing selection. Meanwhile, Khan et al (2017) determined other elements, including security, construction standard, and design features. Hwa (2017) recently found that the developer's reputation is another aspect taken into account in property purchase in Malaysia.

Essentially, purchase decision on housing property is a conclusion after consideration of buying a house or real estate. The decision can be considered as a resolution after several research activities or processes. Several changes take place in the lifestyle of the Malaysian population, which affect the determinant of housing property purchase decision and its impact on housing demand in Malaysia. In offering affordability and quality in housing, the private developers and the government should identify the primary elements leading to the house purchase, ensuring the successful operation of projects, and satisfying the homeowners' long-term goals for living or investment. Moreover, housing property purchase decision may refer to the purchase of shelter, while the house fulfils the buyers' needs and desires (Wang, 2013, as cited in Mariadas et al., 2019). Homebuyers would require a comprehension regarding the aim of housing property purchase and determine the associated elements before reaching the purchase decision (Thaker and Sakaran, 2016). An improved understanding of individuals' selection of residential property is crucial (Ibem et al., 2015). This is similar to the importance of understanding the factors of buyers' understanding of the residence adequacy and satisfaction in the circumstance of properties (Mariadas, 2019). Therefore, this article aim to identify housing purchase decision factors in Malaysia by reviewing and gathering previous research finding in Malaysia.

\section{Research Objective}

The main objective of the research is to identify housing purchase decision factors in Malaysia,

\section{Research Methodology}

This study is in the archival category, with its outline functioning as a review of the empirical literature on the factors of housing purchase decision in Malaysia. Relevant data in this study were obtained through secondary sources, namely academic journals, conference papers, articles, textbooks, and the World Wide Web (cyber internet). This research collected nine relevant previous research papers related to housing purchase decision in Malaysia to develop a new comprehensive for an improved indicator of the purchase decision. Additionally, local previous research papers were used to match this indicator with local cultures or norms.

\section{Factors Influencing Housing Purchase Decision}

Table 1 show the summary of previous research that has been conducted in Malaysia related to housing purchase decision and Table 2 shows the similarity between the factors of housing purchase decision. 
Table 1: Previous research on housing purchase decision factors

\begin{tabular}{|c|c|}
\hline Previous research & Purchase decision factors \\
\hline $\begin{array}{l}\text { Factors Influencing First } \\
\text { Home Purchase Decision } \\
\text { of Middle-Income Earners } \\
\text { (M40) in Selangor, } \\
\text { Malaysia }\end{array}$ & $\begin{array}{l}\text { i.Financial; } \\
\text { ii.Location; } \\
\text { iii.Neighbourhood; } \\
\text { iv.Structural attributes. }\end{array}$ \\
\hline $\begin{array}{l}\text { Factors Affecting the } \\
\text { Housing Preferences of } \\
\text { Homebuyers in Kuala } \\
\text { Lumpur }\end{array}$ & $\begin{array}{l}\text { i.Availability of shop, retail stores, public } \\
\text { infrastructure, school, and workplace } \\
\text { nearby; } \\
\text { ii.Level of security in the neighbourhood, } \\
\text { pollution, guarded and gated security, green } \\
\text { environment, and clean surrounding; } \\
\text { iii.Financial status-housing price, mortgage } \\
\text { loan, payment terms, income level. }\end{array}$ \\
\hline
\end{tabular}

Author(s)

Mariadas, P.A.,

Abdullah, H. and

Abdullah, N. (2019)

\begin{tabular}{lll}
\hline The Effect of Superstitious & i.Superstitious belief -numerology, location & Hui, M. K., Wai, \\
Belief on Property & selection, street features, cross and T & WC. W., and Mei, \\
Purchase Intention & junctions, waste ponds. & N. S. (2019)
\end{tabular}

\begin{tabular}{|c|c|c|}
\hline $\begin{array}{l}\text { Housing Preferences for } \\
\text { First Time Home Buyer in } \\
\text { Malaysia }\end{array}$ & $\begin{array}{l}\text { i.Demographic; } \\
\text { ii.Financial; } \\
\text { iii.Location; } \\
\text { iv.Structure; } \\
\text { v.Neighbourhood; } \\
\text { vi.Economic. }\end{array}$ & $\begin{array}{l}\text { Khan, P. A. M. } \\
\text { Azmi, A., Juhari, N. } \\
\text { H., Khair, N., Daud, } \\
\text { S. Z. (2017) }\end{array}$ \\
\hline $\begin{array}{l}\text { Understanding Factors } \\
\text { that Influence House } \\
\text { Purchase Intention among } \\
\text { Consumer in Kota } \\
\text { Kinabalu: An Application } \\
\text { of Buyer Behaviour Model } \\
\text { Theory }\end{array}$ & $\begin{array}{l}\text { i.House features - construction, duration, } \\
\text { and house size; } \\
\text { ii.Living space - number of house floors and } \\
\text { bathrooms; } \\
\text { iii.Financing - monthly repayment, the interest } \\
\text { rate of the loan, loan repayment duration, } \\
\text { processing fee, the house cost; } \\
\text { iv.Distance - distance from the recreation } \\
\text { centre, market, business centre, school, the } \\
\text { width of the adjacent street; } \\
\text { v. Environment - noise, pollution, nearby } \\
\text { traffic; } \\
\text { vi.Superstition - number } 13,8,4 \text {; } \\
\text { vii.Superstition - ghost-house near the } \\
\text { graveyard, house assumed to be a house, } \\
\text { black-painted house; } \\
\text { viii.Developer brand - a renowned brand of a } \\
\text { property developer, the high price of the } \\
\text { house. }\end{array}$ & $\begin{array}{l}\text { Chia, J., Harun, A., } \\
\text { Mohd Kassim, } \\
\text { A.W., Martin, D. } \\
\text { Kepal, and Noreina } \\
\text { (2016) }\end{array}$ \\
\hline
\end{tabular}

Thanaraju, P., Khan, P. A. M., Juhari, N. H., Sivanthan, S., Khair, N. (2019) 


\begin{tabular}{|c|c|c|}
\hline $\begin{array}{l}\text { Attributes Influencing } \\
\text { Homebuyers' Purchase } \\
\text { Decision: A Study of } \\
\text { Residential Property in } \\
\text { Setia Alam }\end{array}$ & $\begin{array}{l}\text { i.Demographic - age, gender, marital status, } \\
\text { ethnicity, academic achievement, amount } \\
\text { of household, basic information on monthly } \\
\text { gross salary, property ownership } \\
\text { ii.Property features - house price, category, } \\
\text { finishing, design, age, property name } \\
\text { iii.Property appearance - house outer design, } \\
\text { layout scheme, built-up area, house } \\
\text { appearance, land area, and topography } \\
\text { iv.Property area - academy, environment, } \\
\text { safety, traffic, commercial district, facilities, } \\
\text { workplace. }\end{array}$ & San, C. (2016) \\
\hline $\begin{array}{l}\text { Influencing Factors of } \\
\text { Property Buyer in Hillside } \\
\text { Residential Development }\end{array}$ & $\begin{array}{l}\text { i.Price; } \\
\text { ii.Location; } \\
\text { iii.Design; } \\
\text { iv.View and ventilation; } \\
\text { v.Type of neighbourhood; } \\
\text { vi.Facilities and amenities; } \\
\text { vii.Feng Shui elements; } \\
\text { viii.Prestige, luxury, and style. }\end{array}$ & $\begin{array}{l}\text { Salleh, N. A., Zoher, } \\
\text { S. A., Mahayuddin, } \\
\text { S. A., and Abdul, Y. } \\
\text { (2015) }\end{array}$ \\
\hline $\begin{array}{l}\text { The Influence of Housing } \\
\text { Components on Prices of } \\
\text { Residential Houses: A } \\
\text { Review of Literature }\end{array}$ & $\begin{array}{l}\text { i.Location; } \\
\text { ii.Residential dwelling; } \\
\text { iii.Neighbourhood. }\end{array}$ & $\begin{array}{l}\text { Musa, Usman, Wan } \\
\text { Yusoff, and Wan } \\
\text { Zahari (2015) }\end{array}$ \\
\hline $\begin{array}{l}\text { First-Time Homebuyers: } \\
\text { Factors Influencing } \\
\text { Decision Making }\end{array}$ & $\begin{array}{l}\text { i.Finance/economy - house cost, payment } \\
\text { conditions, and capability to gain funds; } \\
\text { ii.Location - Closeness to the workplace, } \\
\text { facilities, city centres, and accessibility } \\
\text { to public transport, main road, and } \\
\text { highway; } \\
\text { iii. Neighbourhood - peaceful area, natural } \\
\text { environment, and insignificant rates of } \\
\text { crime in a district; } \\
\text { iv.Developer's credibility - credible } \\
\text { developer; } \\
\text { v.Interior space and design - building size, } \\
\text { storey number, development of layout, } \\
\text { bedroom and bathroom count, and } \\
\text { finishing category and standard; } \\
\text { vi. Family life cycle - the small size of the } \\
\text { new house, marriage, family-expanding; } \\
\text { vii. House outer design - garden size and } \\
\text { building features. }\end{array}$ & $\begin{array}{l}\text { Abdullah, L., } \\
\text { Mohd Nor, I. B., } \\
\text { Junaidi, N., and } \\
\text { Arshad, H. (2012) }\end{array}$ \\
\hline
\end{tabular}


Table 2: The similarity between the factors of the purchase decision

\begin{tabular}{|c|c|c|}
\hline Factors & Authors & Indicator \\
\hline Finance & $\begin{array}{l}\text { Mariadas et.al., 2019; } \\
\text { Thanaraju et al., 2019; } \\
\text { Khan et al., 2017; } \\
\text { San, C. 2016; } \\
\text { Chia et al., 2016; } \\
\text { Salleh et al., 2015; } \\
\text { Abdullah et al., 2012 }\end{array}$ & $\begin{array}{l}\text { i.House price; } \\
\text { ii.House promotion; } \\
\text { iii.House rebate; } \\
\text { iv.Housing loan qualification; } \\
\text { v.Loan interest rate; } \\
\text { vi.Monthly instalment; } \\
\text { vii.Instalment duration; } \\
\text { viii.Other financial commitment. }\end{array}$ \\
\hline Destination & $\begin{array}{l}\text { Mariadas, et.al., 2019; } \\
\text { Thanaraju, et al. 2019; } \\
\text { Khan, et al. 2017; } \\
\text { Chia, et al. 2016; } \\
\text { Salleh, et al. 2015; } \\
\text { Musa, et al. 2015; } \\
\text { Abdullah, et al. 2012; }\end{array}$ & $\begin{array}{l}\text { i.Near the health centre; } \\
\text { ii.Near the academic centre; } \\
\text { iii.Near the safety centre; } \\
\text { iv.Near the community centre; } \\
\text { v.Near the finance and banking centre; } \\
\text { vi.Near the sport centre; } \\
\text { vii.Near public transport; } \\
\text { viii.Near the shopping facilities; } \\
\text { ix.Near the supermarket; } \\
\text { x.Near the main road; } \\
\text { xi.Near the government office; } \\
\text { xii.The location has the potential to increase the } \\
\text { market value. }\end{array}$ \\
\hline Environment & Chia et al., 2016; & $\begin{array}{l}\text { i.Physical environment } \\
\text { - Green environment; } \\
\text { - Clean environment; } \\
\text { - Tranquil environment; } \\
\text { - Cell-planned environment; } \\
\text { environment. } \\
\text { ii.Social environment } \\
\text { - Exclusive environment; } \\
\text { - Crime-free environment; } \\
\text { - Elite community environment; } \\
\text { - } \text { Open-minded community } \\
\text { - Multi-cultural community environment. }\end{array}$ \\
\hline Neighbourhood & $\begin{array}{l}\text { Mariadas et. al., 2019; } \\
\text { Khan et al., 2017; } \\
\text { San, C., 2016; } \\
\text { Salleh et al., 2015; } \\
\text { Musa et al., 2015; } \\
\text { Abdullah et al., 2012; }\end{array}$ & $\begin{array}{l}\text { i.Gated neighbourhood; } \\
\text { ii.Individual neighbourhood; } \\
\text { iii.Mixed neighbourhood; } \\
\text { iv.Local neighbourhood; } \\
\text { v.International neighbourhood; } \\
\text { vi.Urban neighbourhood; } \\
\text { vii.Suburban neighbourhood; } \\
\text { viii.Rural neighbourhood. }\end{array}$ \\
\hline
\end{tabular}




\begin{tabular}{|c|c|c|}
\hline $\begin{array}{l}\text { Infrastructure } \\
\text { facilities }\end{array}$ & Salleh et al., 2015; & $\begin{array}{l}\text { i.Transportation: e.g., roads, bridges, airports, } \\
\text { and ports; } \\
\text { ii.Energy: e.g., electricity; } \\
\text { iii.Water: e.g., clean water supply and } \\
\text { management; } \\
\text { iv.Safety and resilience: e.g., police station, } \\
\text { firefighter; } \\
\text { v.Financial: e.g., bank, money changer } \\
\text { vi.Health: e.g., hospital, clinics, veterinary clinics; } \\
\text { vii.Educational: e.g., nursery, school, university; } \\
\text { viii.Network: e.g., Telco substation; } \\
\text { ix.Public spaces: e.g., parks, beaches, nature } \\
\text { reserves; } \\
\text { x.Cultural: e.g., museums, art, and crafts; } \\
\text { xi.Religious: e.g., mosque, church, temple; } \\
\text { xii.Sports: e.g., gym, swimming pools, football } \\
\text { fields. }\end{array}$ \\
\hline $\begin{array}{l}\text { Developer } \\
\text { service quality }\end{array}$ & $\begin{array}{l}\text { Chia, et al. 2016; } \\
\text { Abdullah, et al. 2012; }\end{array}$ & $\begin{array}{l}\text { i.Developer brands; } \\
\text { ii.Achieved awards; } \\
\text { iii.Recommendations; } \\
\text { iv.Readiness to respond; } \\
\text { v.Safe transaction for housing; } \\
\text { vi.Constant professionalism of the employees; } \\
\text { vii.Employees' understanding of what is needed } \\
\quad \text { for home buyers; } \\
\text { viii.Employees who look prim and proper; } \\
\text { ix.Convenient service hours; } \\
\text { x.Presence of after-sales service. }\end{array}$ \\
\hline $\begin{array}{l}\text { Superstition } \\
\text { belief }\end{array}$ & $\begin{array}{l}\text { Hui et al., 2019; } \\
\text { Chia et al., 2016; } \\
\text { Salleh et al., 2015; }\end{array}$ & $\begin{array}{l}\text { i.Feng Shui, Wasthu Sastra prediction; } \\
\text { ii.House history: unnatural death, such as } \\
\text { murder or suicide, and horrifying events; } \\
\text { iii.House number: No. 4, 14, 44, etc.; } \\
\text { iv. House location: the "T" junction position, a } \\
\text { position below road level, etc.; } \\
\text { v. House view: a view from the graveyard, } \\
\text { hospital, and religious sites; } \\
\text { vi.House direction: facing the North, South, West, } \\
\text { etc.; } \\
\text { vii. Neighbourhood: many empty or resold houses; } \\
\text { viii.The dwelling features: main door, floor plan } \\
\text { layout, etc. }\end{array}$ \\
\hline
\end{tabular}




\begin{tabular}{|c|c|c|}
\hline $\begin{array}{l}\text { Dwelling } \\
\text { characteristics }\end{array}$ & $\begin{array}{l}\text { Mariadas et al., 2019; } \\
\text { Khan et al., 2017; } \\
\text { San, C., 2016; } \\
\text { Chia et al., 2016; } \\
\text { Salleh et al., 2015; } \\
\text { Musa et al., 2015; } \\
\text { Abdullah et al., 2012; }\end{array}$ & $\begin{array}{l}\text { i.Land size; } \\
\text { ii.Built-up size; } \\
\text { iii.Number of house storeys; } \\
\text { iv.House design; } \\
\text { v.House layout; } \\
\text { vi.Number of bedrooms; } \\
\text { vii.Number of bathrooms; } \\
\text { viii.Furnished house; } \\
\text { ix.Balcony; } \\
\text { x.Home yard; } \\
\text { xi.Building materials; } \\
\text { xii.The density of housing scheme; } \\
\text { xiii.Type of housing scheme title (strata or } \\
\text { individual); } \\
\text { xiv.Type of hosing (landed or high-rise); } \\
\text { xv.Type of tenure (Freehold or leasehold or Bumi- } \\
\text { reserved). }\end{array}$ \\
\hline $\begin{array}{l}\text { Demographic } \\
\text { background }\end{array}$ & $\begin{array}{l}\text { Khan et al., 2017; } \\
\text { San, C., 2016; } \\
\text { Abdullah et al., 2012; }\end{array}$ & $\begin{array}{l}\text { i.Hometown area; } \\
\text { ii.Working area; } \\
\text { iii.Affordability; } \\
\text { iv.Number of households; } \\
\text { v.Ethnicity ; } \\
\text { vi.Monarchy status. }\end{array}$ \\
\hline
\end{tabular}

Based on Tabele 1 and Table 2, there are nine (9) factors has been identified which namely as:

\section{Demographic Factor}

Essentially, a demographic factor impacts residents' selection (Hurtubia et al., 2010). According to Jayantha and Lau (2016), the demographic background of the buyers, including income level, age, and marital status could influence the decision on property purchase. Lutfi (2010) stated that individuals of 29 years old and younger have a lower possibility of purchasing real estate as they would not be able to be financially stable. Furthermore, Bajari Kahn (2005) identified country or ethnicity as a socio-economic element, which could be distinguished through the nation and skin colour. Every ethnic group in Malaysia consists of diverse cultures and points of view related to house purchase (San, 2016).

Provided that education represents lifestyle buyers, higher academic level is known as the primary factor of the housing system (Barlow and Ozaki, 2003). Hurtubia et al. (2010) recorded that diverse academic degrees would contribute to various home categories being demanded and the purchase of high-priced houses (Barlow and Ozaki, 2003). Meanwhile, a lower academic degree would lead to a reduced willingness for house ownership (Majid, 2010). Working adults have a preference for houses near their workplace due to their need to prevent excessive commuting time to the workplace (Jun and Jones, 2013). Moreover, salary degree would also impact the housing market cycle (Garcia and Hernandez, 2008). Besides the tendency of individuals with higher salaries to purchase higher-cost houses (Ariffin, 2010), individuals with a low salary would face challenges in house ownership (Tunner and Lue, 2009). 


\section{Financial Factor}

Financial factors are significant in a residence purchase decision. Finance refers to the financial health of a person, which requires money, salary level, payment, interest degree, and loan. It also indicates mortgage presence, conditions for the purchase, house cost, property evaluation value, chances for swift acknowledgement, and duration for waiting (Chia, et al., 2016; Jamil, 2015; Mariadas, et al., 2019; Opoku and Abdul-Muhmin, 2010; Yong Zhou, 2009). Finance could also be identified as a long-term loan with a bank to purchase a house (Jan et al., 2016), which has also become the most significant element in house cost in Malaysia (Chia, 2016; Razak, 2013).

\section{Location factor}

Location may refer to a point of interaction between individuals and facilities to fulfil their liking (Zrobek et al., 2015). An ideal destination would be important despite the fluctuation of the real estate market in the future, which is in line with the saying, "thou can make an ugly house attractive but thou can't make a bad location great". Furthermore, the investment of houses placed in an ideal destination would contribute to profits. Moreover, Oloke et al. (2013) revealed that the largest rent capacity as location emerged as a mediating factor with an excellent location advantage, which impacted the investors' or buyers' purchase decision. Location refers to the ability of the selected house to be accessible from the nearest town, shopping facilities, and relatives' house (Khan et al., 2017). Adegoke (2014) indicated that the locations of all categories of residential features were based on the accessibility to the buyers' destinations.

\section{Dwelling Characteristics Factor}

Dwelling characteristics refer to the structural elements of housing, which consist of the duration of dwelling, room size, design quality, the number of toilets, bathrooms, and living rooms, condition of construction equipment, wall fence and gate, the scheme of dwellings, landscaping, and presence of space (Musa et al., 2016). Dwelling characteristics comprise the conditions of the building, house design, finishing, and the design inside and outside the building (Adair et al., 1996; Chia et al., 2015; Daly et al., 2003; Sengul, Yasemin, and Eda, 2010; Opuku and Abdul-Muhmin, 2010).

Hong (2012) highlighted that house dwelling comprised the size of the dining hall, living halls, number of bathrooms, and bedrooms. Jayantha and Lau (2016) argued that neighbourhood facilities also have several impacts on housing property buying decision, including the presence of a landscape of park or garden, clubhouse, swimming pool, and gymnasium. It was also perceived that the common perception among residence owners with a higher status and symbol own a larger residence (Jun, 2013). A property with an either 'freehold' or 'leasehold' title also affects buyers' preferences during the purchase decision. Hong (2010) stated that the 'leasehold' title indicates the property owner's need to return the land or pay a premium to the government after 99 years or whenever the leasing duration is due. However, Mariadas et al. (2019) stated that buyers prefer the freehold title as they are not required to return their building and land to the government.

\section{Neighbourhood Factor}

According to Sean and Hong (2014), a neighbourhood is an area where communities reside together. Jayantha and Lau (2016) highlighted that neighbourhood involves interactions 
between the communities, appealing surrounding and view, a peaceful site for getting together and supporting one another. Households have a higher willingness to invest more for a good neighbourhood in their selection of a home or residential property (Thaker and Sakaran, 2016). According to Tan (2016), homebuyers would purchase a guarded residential property to indicate their social ranking. Additionally, Carolina (2013) stated that buyers with good financial health prefer a 'higher-income' neighbourhood as fewer renters are present.

\section{Infrastructure Facilities Factor}

The ability for basic infrastructure facilities in the area to be accessible is a significant element. Khan et al. (2017) stated that the most crucial decision-making process for home is the presence of amenities, including location, playground, sports area, and institution, in which the symbolised and socialised cultures should be taken into account. The general amenities, including public transport and electricity and water supplies, are essential in the property buyer's purchase decision. Specifically, public transport is inter-related to economic development, which facilitates the distribution of information regarding business prospects, leads to sprawl reduction, and develops an ideal atmosphere of the site. Additionally, the effectiveness of the facilities leads to a sense of security among the buyers during their residency (Almatarneh, 2013). A properly schemed zoning of land use for the supervision of open and recreational spaces, housing area, and community amenities is one of the elements influencing individuals' residency (Yakob et al., 2012).

\section{Environment Factor}

Khan et al. (2017) divided the environment into physical and social environments. Specifically, the physical environment comprises the physical feature and the quality of the outer side of the building, proximity to natural areas, physical disruptions including pollution and noise, entrance, and maintenance standard. Meanwhile, the social environment consists of status, security, social connection, and lifestyle within the selected site.

\section{Developer service quality factors}

High sales have been recorded for various properties as they are developed by renowned developers who are granted with various awards. Cheng and Cheok (2008) and Razak (2013) highlighted that the developer brand has a significant influence on the buyers' buying decision. It was also found that developers are ranked by the buyers based on brand attributes, trend, investment, and professionalism concerning buying decision.

\section{Superstition Belief Factor}

Chinese superstitions have a significant effect on house prices (Fortin, Hill, and Huang, 2014). Superstitious beliefs still play a role in the housing purchase decision and affect the younger generation in their action and behaviour as the beliefs are passed down from one generation to another (Hui, Wai, and Mei, 2019). Housing properties were suggested to be developed far from the waste ponds and placed higher than the main road instead of the cross junction or T-junction. This is followed by the replacement of address and floor numbers, which are associated with number 4 and an alphabet (e.g., ' $A$ '). Notably, these two factors have significant influences on the buyers' attitude, belief, and perceived behavioural control, indicating a strong concern when potential buyers attempt to purchase a residential property (Hui, Wai and Mei, 2019). 
To achieve Feng Shui, the property buyer should identify the lot position, neighbourhood, and site (Kong and Chiong, 2006; Tchi, 2013). Therefore, the analysis of the terrain, position, and direction of the property is crucial to guarantee the condition and degree of comfort, which would impact the health and fortune of its occupants (Chu, Hsu, and Hsieh, 2017). Furthermore, an ideal location providing good energy would be a location surrounded by hills, backed by mountains ( $\mathrm{Wu}, \mathrm{Yau}$, and Lu, 2012), and accompanied with an open space in front of the house, which showcases a lake or a river with water flowing in it (Xu, 1997).

However, streets or roads of any shapes or types, such as a narrow path, country road, trunk road, main road or highway, are believed to bring negativity to the household if positioned higher than the property itself (Fong, 2007). Besides, Fong (2007) highlighted that a house positioned at a cross junction or a T-junction is not always a proper choice as a residency. Moreover, it is believed by several individuals that lucky numbers could contribute to life fortunes (Too, 1997). However, number ' 4 ' is considered an unlucky number as the pronunciation of it is similar to the pronunciation of the word 'death' in Cantonese (Rehm, Chen, and Filippova, 2018). Buyers also prevent the purchase of houses with unlucky numbers used in the addresses. Despite their claim of not believing in Feng-Shui, they show concerns regarding the possibility for the property to be resold (Boyer, 1995).

\section{Conclusion}

Housing is one of the necessities for all individuals. Determining diverse elements influencing housing purchase decision would be crucial for individuals with interests in this matter. Accordingly, this article gathered the relevant indicators to develop an improved comprehensive indicator for future study. This was followed by identification and categorisation of housing purchase decision factors into nine factors, namely demographic background, finance, location, dwelling features, neighbourhood, infrastructure facilities, environment, developer service quality, and superstitious belief. Overall, these factors might produce different results from each individual due to their different needs and affordability.

\section{Acknowledgements}

This research received full support from Universiti Putra Malaysia IPM Grant - Current Issues 9681400 (UPM RMC).

\section{References}

Abdullah, L., Nor, S. I. B. M., Jumadi, S. N., \& Arshad, S. H. (2012). First-Time Homebuyers: Factors influencing Decision-Making. In International Conference on Innovation and Technology for Sustainable Built Environment (pp. 249-254).

Adegoke, O. (2014). Critical factors determining rental value of residential property in Ibadan metropolis, Nigeria. Property Management, 32(3), 224-240.

Almatarneh, R. T. (2013). Choices and changes in the housing market and community preferences: Reasons for the emergence of gated communities in Egypt: A case study of Egypt's Greater Cairo Region. Ain Shams Engineering Journal, 4(3), 563-583.

Ariffin N. R., Zahari R. K., Nadarajah S. (2010). Residential Satisfaction in private Low-Cost Housing in the urban area: A case study of the Klang Valley, Malaysia. Urban Dynamic \& Housing Change-Crossing into the 2nd Decade of the 3rd Millennium.22rd International Housing Research Conference, 4-7 July Istanbul. 
Bajari, P., Kahn, M. E. (2005). Estimating Housing Demand with an Application to Explaining Racial Segregation in Cities. Journal of Business \& Economic Statistics. Volume 23 Issue 1 (Jan). Pp. 20-33.

Barlow, J., Ozaki, R. (2003). Achieving 'Customer Focus' In Private House Building: Current Practice And Lessons From Other Industries. Housing Studies.Volume 18 Number 1 (Jan). Pp. 87-101.

Boyer, T. M. (1995). Home Sweet Home? An Analysis of Taiwanese Immigration Since 1986 and the Present Status of the Taiwanese Community in Auckland, in An EthnoGeography of Taiwanese, Japanese and Filipino Immigrants in Auckland, Occasional Paper 28, Yoon, H. (ed.). Department of Geography, University of Auckland, New Zealand.

Cheng, F. F., \& Cheok, J. (2008). Importance of branding for property developers in Malaysia. Sunway Academic Journal, 5, 65-81.

Chia, J., Harun, A., Kassim, M. A. W., Martin, D., \& Kepal, N. (2016). Understanding Factors that Influence House Purchase Intention among Consumer in Kota Kinabalu: An Application of Buyer Behavior Model Theory. Journal of Technology Management \& Business, Vol. 03, No. 02, 2016, ISSN: 2289-7224.

Chu, Y. C., Hsu, M. F., \& Hsieh, C. M. (2017). The Impacts of Site Selection and Planning of a Historic Settlement on a Sustainable Residence. Applied Ecology \& Environmental Research, 15(2), 145-157.

Fierro, K. P., Fullerton Jr., T. M., \& DonjuanCallejo, K. E. (2009), Housing Attribute Preference in a Northern Mexico Metropolitan. Atlantic Economic Journal, 37(2):159-172.

Fong, J. (2007). Feng Shui in the City: A Practical Handbook for Modern Urban Living. Shah Alam, Selangor Darul Ehsan: Marshall Cavendish.

Fortin, N. M., Hill, A. J., Huang, J. (2014). Superstition in the Housing Market. Economic Inquiry, 52(3), 974-993. doi:10.1111/ecin.12066

Garcia, J. A. B., Hernandez, J. E. R. (2008). Housing Demand in Spain according to dwelling type: Microeconometric evidence. Regional Science \& Urban Economics.Volume 38 Issue 4 (Jul). Pp. 363-377.

Hong. T. (2010). The effect of housing characteristics on neighbourhood stability of homeownership. International Journal of Business \& Emerging Market, 2(3), 286 - 304.

Hui, M. K., Wai, W. C. W., Mei, N. S. (2019). The effect of Superstitious Belief on Property Purchase Intention. International Journal of Real Estate Studies.13 (2)/2019, 1-13.

Hurtubia, B., Gallay, O., \& Bielaire, M. (2010). Attributes of household, locations and real estate for land-use modelling. Sustain City Working Paper, 2.7. Lausanne: EPFL.

Hwa, G. O. (2017), Developer's reputation of topmost concern, The Star Online, retrieved from http://www.thestar.com.my/metro/community/2017/04/12/developersreputation-oftopmost-concern-visitors-to-starpropertymyawards-2017-showcasesaylocatio/accessed on 26 August 2017

Ibem, Adeboye, and Alagbe. (2015). Similarities and differences in residents' perception of housing adequacy and residential satisfaction. Journal of Building Performance, 6(1), 114.

Jamil, F. (2015). The Role of Installment Buying Plans in Increasing the Impulse Buying Behavior among Jordanian House Holds. Jmr, 8(1), 110.

Jan, Bardhan, Sarkar and Kumar. (2016). Framework to assess and locate affordable and accessible housing for developing nations: Empirical evidence from Mumbai. Habitat International, 5(7), 88-99. 
Jayantha, W. M., and Ming, J. L. (2016). Buyers' property asset purchase decisions: an empirical study on the high-end residential property market in Hong Kong. International Journal of Strategic Property Management, 20(1), 1-16.

Jun, and Jones, M. (2013). Residential density and location decisions: The factors affecting homeowners' choice of denser neighbourhoods. Housing \& Society, 38(2), 121-146.

Khan, P. A. M., Azmi, A., Juhari, N. H., Khair, N., Daud, S. Z. (2017). Housing Preference for First Time Home Buyer in Malaysia. International Journal of Real Estate Studies, Volume 11 Number 2.

Lutfi. (2010) Relationship between demographic factors and Investment Decision in Surabaya. Journal of Economics, Business and Accountancy Venture, Volume 13, No. 3. December 2010, Pages 213-224 Accreditation No 110/DIKTI/Lep/2009.

Mariadas, P. A., Abdullah, H., \& Abdullah, N. (2019). Factors Influencing the First Home Purchase Decision of Middle-Income earners (M40) in Selangor, Malaysia. Journal of Social Sciences \& Humanities, Vol. 16, No. 1(1-11). ISSN: 1823-884x.

Majid, R. A. (2010). Faktor-faktor yang Mempengaruhi Permintaan Harta Tanah kediaman di Malaysia, unpublished manuscript thesis. University of Malaya, Kuala Lumpur.

Musa, U., \& Yusoff, W., Zahari, W. (2015). The Influence of Housing Components on Prices of Residential Houses: A Review of Literature in 9th Malaysian Technical Universities Conference on Engineering and Technology 2015 (MUCET 2015), 11 - 13 October 2015, Johor Baharu, Malaysia.

Oloke, O., Ayedun, C., and Ignatus, O. (2013). An Examination of Estate Surveyors and Valuers' Perception of Flood Risk on Residential Property Value in Lagos State, Nigeria. Ethiopian Journal of Environmental Studies and Management, 6(6), 784.

Opoku, R. A., \& Abdul-Muhmin, A. G. (2010). Housing preferences and attribute importance among low-income consumers in Saudi Arabia. Habitat International, 34, 219-227.

Razak, I., Ibrahim, R., Hoo, J., Osman, I., \& Alias, Z. (2013). Purchasing Intention towards Real Estate Development in Setia Alam, Shah Alam: Evidence from Malaysia. International Journal of Business, Humanities \& Technology, 3(6), 66-75.

Rehm, M., Chen, S., \& Filippova, O. (2018). House prices and superstition among ethnic Chinese and non-Chinese homebuyers in Auckland, New Zealand. International Journal of Housing Markets \& Analysis, 11(1), 34-44.

Reid, C. (2013). To Buy or Not to Buy? Understanding Tenure Preferences and the DecisionMaking Processes of Lower Income Households. Cambridge, MA: Joint Center for Housing Studies of Harvard University.

Salleh, N. A., Zoher, S. A., Mahayuddin, S. A., Abdul, Y. (2015). Influencing Factors of Property Buyer in Hillside Residential Development. Asian Conference on Environment-Behaviour Studies Chung-Ang University, Seoul, S. Korea, 25-27 August 2014.

San, C. (2016). Attributes influencing homebuyers' purchase decision: A study of residential property in Setia Alam (Master's thesis, University Tunku Abdul Rahman, Kuala Lumpur).

Sean, S., and Hong. T. (2014). Factors affecting the purchase decision of investors in the residential property market in Malaysia. Journal of Surveying, Construction and Property (JSCP), 5(2), 1985-7527.

Tan, T. (2016). Neighbourhood satisfaction: responses from residents of green townships in Malaysia. International Journal of Housing Markets \& Analysis, 9(1), 137 - 155. 
Thaker, H., and Sakaran, K. (2016). Prioritisation of key attributes influencing the decision to purchase a residential property in Malaysia. International Journal of Housing Markets \& Analysis, 9(4), 446-467.

Thanaraju, P., Khan. P. A. M., Juhari, N. H., Sivanthan, S., Khair, N. (2019). Factors Affecting the Housing Preferences of Homebuyers in Kuala Lumpur. Journal of the Malaysian Institute of Planners. Vol. 17, Issue 1 (2019), Page 138-148

Too, L. (1997). Feng Shui Fundamentals: Wealth. Element Books, Rockport, Mass.

Turner, T. M., Lue, H. (2009). Homeownership, Wealth Accumulation and Income Status. Journal of Housing Economics.Volume 18 Issue 2 (Jun). Pp. 104- 114.

Wu, W. Y., Yau, O. H. M., Lu, H. Y. (2012). Feng Shui Principles in Residential Housing Selection. Psychology \& Marketing, 29(7), 502-518.

$\mathrm{Xu}, \mathrm{P}$. (1997). Feng shui as a clue: identifying the landform patterns of impact zones from the 2013 historic mountain floods in boulder and nearby areas, Colorado, USA. International Scientific Journal Environmental Science.

Yakob, H., Yusof, F., \& Hamdan, H. (2012). Land-use Regulations towards a Sustainable Urban Housing: Klang Valley Conurbation. Procedia - Social and Behavioural Science, 68(0),578-589.

Yongzhou, H. (2009). Housing price bubbles in Beijing and Shanghai. International Journal of Housing Markets \& Analysis, 3(1), 17-37.

Zubek, S., Trojanek, M., Skolnik, A. \& Trojanek, R. (2015). The Influence of Environmental Factors on Property Buyers' Choice of Residential Location in Poland. Journal of International Studies, 8(3), 164-174.

Zyed, Z. A. S., Aziz, W. N. A. W. A., \& Hanif, N. R. (2016), Housing Affordability Problems among Young Households, Journal of Surveying, Construction \& Property, 7(1):1-18. Architectural Design and Space Management Concepts, Butterworth-Heinemann, Boston

Factors to Consider When Buying a House. (2017). Retrieved April 4, 2020, from https://www.fastrepayhomeloan.com.au/7-factors-to-consider-when-buying-a-house/ Marketing gimmicks: Here's how some developers get too creative. (2019). Retrieved April 6, 2020, from https://www.iproperty.com.my/guides/5-things-you-need-to-know-aboutmarketing-gimmicks/ 